\title{
A Study of the Art of Painting in Kabul
}

\author{
Abdul Qadir Sarwari \\ Assistant Professor, Herat University, Afghanistan \\ https://orcid.org/0000-0002-0371-184X
}

\section{OPEN ACCESS}

Manuscript ID:

ASH-2020-08023422

Volume: 8

Issue: 2

Month: October

Year: 2020

P-ISSN: 2321-788X

E-ISSN: 2582-0397

Received: 30.07 .2020

Accepted: 02.09.2020

Published: 01.10.2020

Citation:

Sarwari, Abdul Qadir.

"A Study of the Art of Painting in Kabul." Shanlax International Journal of Arts, Science and Humanities, vol. 8, no. 2, 2020, pp. 16-26.

DOI:

https://doi.org/10.34293/ sijash.v8i2.3422

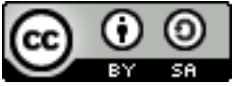

This work is licensed under a Creative Commons AttributionShareAlike 4.0

International License

\begin{abstract}
Today, in most countries, painting has made great progress, along with science and technology. Recently, relative attention have been paid in the scientific, cultural, and social fields in Afghanistan, especially in Kabul, but little progress in the field of painting. In this research, an attempt was made to study the art of painting in Kabul, which its result would be important for those who are interested in the art of painting.

Both library and field research methods have been used for collecting data. In the background section, some authoritative books, articles, and magazines have been used. In the field research method, some observations and interviews were used to collect data. The aim of the study was to study the art of painting in Kabul from the perspective of experts, professors of the Kabul College of Fine Arts, and directors of painting galleries in Kabul. It is summarized as follows:

Painting in Kabul is relatively stagnant due to insecurity, war, religious prejudice, the irresponsibility of the Ministry of Information and Culture, and the lack of public awareness. Only from a specialist, slight changes can be seen in the works of painters. These changes have taken place in the field of painting since 2002, due to the movement of artists abroad, and have opened up new perspectives. Some of the painters' works represent their efforts in search of having a unique and new method. However, most of the paintings are portraying the same method and repetitive subjects as in the past.
\end{abstract}

Keywords: Afghanistan, Kabul, Painting, Realism, Style and Modern Painting

\section{Introduction}

The art of painting in Afghanistan has a history of several thousand years. The paintings on the walls of Hazar Som in Samangan and paintings in Bamyan are among the oldest examples of painting in Afghanistan.

After the influence of the Greeks in Afghanistan, their style and method of painting had a significant impact on the painting of Afghanistan. Thereupon, the paintings they made on the coins were more valuable and important than the printed coins of Greece in the beauty of their designs. Historians and artists believe that skilled Western painters played a significant role in the creation of such coins. Therefore, it can be said that the beautiful art of painting is a large part of the culture and civilization of Afghanistan, which is representative of the skills and talents in this country.

The aim of this study was to examine the art of painting in Kabul from the perspective of professors, painters, and gallery directors in Kabul, and to observe the author's views and opinions in this regard. The working methods of painters in Kabul, the college of Fine Arts, some existing galleries in Kabul city, and the developments that have taken place in the field of the painting are examined.

In this research study, the introduction to the art of painting, the art of painting, the study of the art of painting in Kabul, and its growth and lack of growth factors have become clear to artists, art students, and art lovers, which is important. 


\section{Research Questions}

1. What style and method do painters in Kabul follow the most?

2. What is the position of painting among people?

3. What is the interest of students and audiences in the art of modern painting?

4. In recent years, what changes have taken place in the field of painting in Kabul?

The above questions are referred to as interview questions.

\section{Art in Afghanistan}

Fine arts, especially painting, miniaturing, sculpturing, and body sculpting, represent a large part of Afghanistan's rich culture and civilization. Our country brought up thousands of artists who have engraved different arts with their strong hands on the stones and letters and have kept them hand in hand with history with all the turbulent events of the time. Paintings are engraved on the foothills of Bamyan with perfection and beauty dating back to several centuries. The art of painting and sculpture in pre-Islamic Afghanistan had reached its peak of perfection and elegance, as a work of art obtained in Hede Jalalabad forms a delicate museum which is inherently a good example of sculpture in the world. In Bagram, the Kushans settled in the 1st to 3 rd centuries. At that time, Greek and Buddhist industries flourished; they left behind extraordinary works of art. Greek and Western civilization and art style influenced Afghan art, which resulted in the formation of beautiful coins.

Following the spread of Islam in Afghanistan, Afghan artists sought to bring the art of painting to the Tazhib (an Arabic word which has been derived from "Sahab" meaning "gold." Tazhib or gilding currently means to draw beautiful patterns of plants or geometrical shapes on the margins of books), Taseer (a combination of Khatai and Eslami motifs in which the motifs of birds, animals, and human faces have also used), and elegance of calligraphy by considering Islamic morale. However, the praise letter of Kelileh and Demneh during the Samanian period and Farrokhi Sistani's poem in praise of Sultan Mahmoud Ghaznavi's Firoozeh Palace indicate that painting and sculpting were also common at that time.
The Timuri period was one of the special and noteworthy periods of Khorasan (Afghanistan) art. During this period, the Herat School was established, widely discussed due to its special features. Many issues have been raised about this school with its artists and works of art. One of the main reasons for this sensitivity is that most art historians and researchers believe this school was the culmination of Khorasan's painting that its artists had achieved a degree of artistic ability that affected not only their previous schools and artists, but the artists of the eras after them were also in the scope of their influences. The reign of Sultan Hussain Bayqara was one of the brightest periods of Timuri culture and civilization in Afghanistan. Considering that culture and civilization flourished during the Timuri era, the reign of Sultan Hussein Bayqara can be considered a brilliant milestone in the entire history of Islamic culture and art. Sultan Hussein Bayqara, with his art and epistemology, as the leader of the orchestra that combines and harmonizes different rhythms, led and harmonized hundreds of prominent cultural-artistic figures. Thus, he established a cultural center in Herat unparalleled in its kind.

Kamaluddin Behzad, a unique and talented artist, with his exclusive and beautiful works not only in the history of the peoples of the East but also in the world's culture, has played a significant role in the development of the art of painting, especially miniature.

\section{The Art of Painting in Kabul}

Since the life of Kamaluddin Behzad, many painters have emerged in many parts of Afghanistan, and their works may be found in many parts of the country, but their fame has not lasted forever. But at the end of the reign of Amir Dost Mohammad Khan, a man named Mohammad Azim was born in Kabul, who was dumb and talked with a gesture. Mohammad Aziz Abkam and Mohammad Sarwar, grandsons of Mohammad Azim, were students of a fine arts school in Kabul.

Mohammad Azim Naghash painted the first picture of Amir Dost Mohammad Khan and the pictures of his princes and family members. He used to sign the works he painted with pens or oil paints under his name, "Mohammad Azim Abram." 
During the time of Abdul Rahman Khan, special attention was paid to painters and artists. Abdul Rahman Khan appointed several young people, such as Mirzamanuddin Khan and Mir Barbik Khan, and a few others to study painting.

The ornate palaces, the garden, and the palace of Bustan Sarai are of the monuments of Abdul Rahman Khan's time. Ostad Hessamuddin, one of the Darbar painters of the time, left paintings on the walls of the above-mentioned palaces. Several examples of the painter's works of art are now in the Kabul Museum. This artist taught many students, including Gholam Mohammad Khan, who was from Miran Maimana and was included in his students by Abdul Rahman Khan.

\section{Professor Gholam Mohammad Maimanagi}

A skilled master of the art of painting was born in the beautiful province of Faryab in 1873, whose name was Gholam Mohammad, son of Abdul Baqi Khan. He lost his father at the age of two or three and immigrated to Kabul at seven. His passionate talent makes him paint his first artwork skillfully and being famous among the elders. Mir Hessamuddin admitted him as his student; he later became one of the greatest masters of art, the most skilled painters, and the most talented Afghan artist.

Maimanagi was interested in oriental style, i.e., miniature and Tazhib, but later, he did lots of his works in a realistic and classic style. He has done his artistic activities in various fields of painting with a dip pen, ballpoint pen, pastel, oil paint, charcoal, and pencil. He mostly followed Rembrandt style and masterfully Behzad's style in miniature. For landscapes in oil painting, he used to apply paints to the canvas (the linen cloth being used for painting) by a special painting knife.

One of Mimangi's masterpiece is a landscape painted in Berlin, Germany. In the painting, the roaring sea is seen in the back of a mountain full of colorful trees. On the left side of the painting, a man and a woman are seen, and several sheep are grazing. The painting is dim, but it is clear that it is autumn, and the color of the leaves has turned red and yellow. The piece of art was photographed in Germany, and the size of the painting is $70 \mathrm{~cm}$ by $120 \mathrm{~cm}$, with an unreliable document (Figure 1).

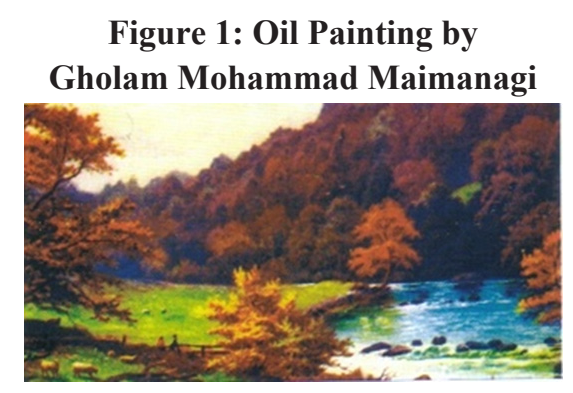

\section{Abdul Ghafoor Breshna}

Abdul Ghafoor Breshna was born on April 10, 1907, in Kabul. He learned calligraphy from his grandmother and studied at Habibieh School until high school. Then, at the age of fourteen, in 1921, he went to Germany with several Kabul youth to study higher education. He completed his studies in painting, lithography, printing, and press in Berlin, Leipzig, Munich, and Bremen cities. Max Liebermann was one of his professors, whom he regularly kept reminding him. Bareshna's entry into the Kabul School of Industry in 1929 after his graduation gave new life to painting, and the main path of the art of painting was determined.

This ambitious artist with enthusiasm and talent entered the field of more modern painting, which had just flourished by Gholam Mohammad Maimanagi, and the classes were still in progress. Breshna's approach to this phenomenon was amazing at the time. Although he had entered Kabul in the early days with a Western spirit, he did not feel alienated from Eastern painting, and soon realized the purpose and aspirations of the environment. With the support of Professor Gholam Mohammad Mimangi, he took the painting from the school grounds to the old alleys of Kabul and the lap of nature. The painting took the form of pristine nature, old alleys, mud houses, trees, and leafy soils, and people's portraits were reflected on sheets of paper and canvas. The students, for the first time, bridged the gap between people and nature and realized the core mission of reviving their country's original culture and art. Breshna, with his realism and his free style features, soon found his place into the hearts of art lovers and expressed his support for the demands of the people in simpler language.

Ostad Breshna had experience in almost all fields of painting and worked masterfully on each of them. 
Just as the dip pen works of Breshna show the power of his creativity, his charcoal and watercolor works (the way she paints with water and color) manifested the elegance and style of his work on the canvas and fabrics with special transparency.

There are many works of art by Breshna exhibited in Egypt, India, New York, the former Soviet Union, Iran, Bulgaria, and Turkey exhibitions.

Breshna worked with watercolors so freely and boldly that the painting brush accepted his obedience (Figure 2). He was also a great portraitist and had such extraordinary power in drawing human portraits that with a few brush strokes, he portrayed the face of the opposite person in a good way with complete resemblance (Figure 2).

\section{Figure 2: Inanimate Nature Painting with Water} Color by Abdul Ghafoor Breshna

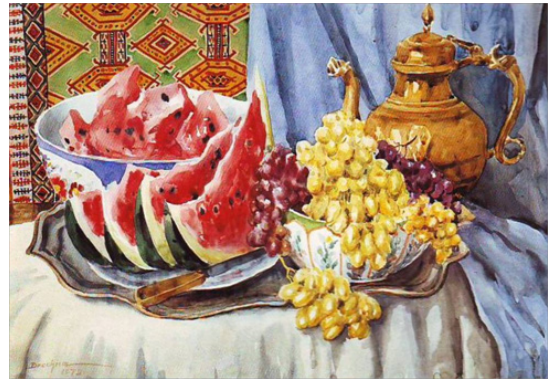

Breshna worked in the realism style and was inspired by the motives of his community.

Figure 3: Kabul Public Garden, watercolor by Abdul Ghafoor Breshna

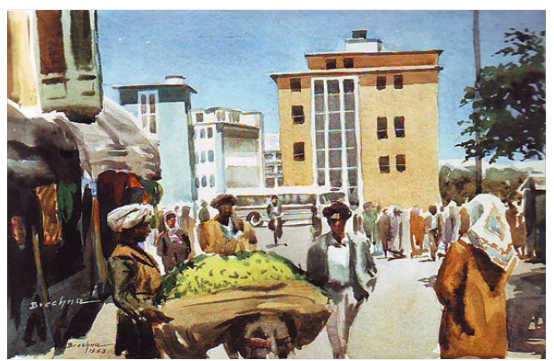

\section{Mohiuddin Shabnam}

Mohiuddin, son of Abdul Rahman, was born in 1935 in the ancient city of Ghazni. After graduating from the twelfth grade of Education institute, he went to the Philippines to pursue higher education in art. Mohiuddin Shabnam worked in modern styles, Impressionism and Graphics, (Figures 4-5).
Figure 4: Butcher Shop, Oil Paint by Ostad Shabnam

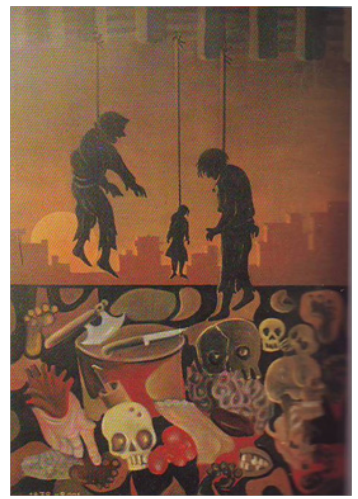

Figure 5: The War Consequence; Oil Paint by Ostad Shabnam

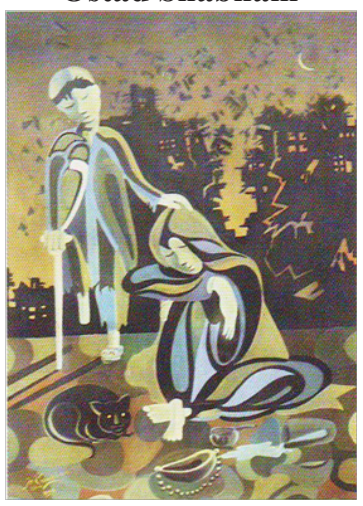

\section{The Current Painters of Kabul}

In the glorious history of Afghanistan, talented and experienced artists and masters have lived and left their works in various fields of visual arts, especially painting. With their effortful teaching, Afghanistan's cultural heritage has been passed down from generation to generation, and they trained competent students and presented them to the community. The professors and painters at the Kabul faculty of Fine Arts, art schools, and freelancer artists prove the claim. It is necessary to introduce a number of these painters as examples in this chapter.

\section{Mohammad Seddiq Zhakfar}

Mohammad Seddiq Zhakfar was born in 1962 in the ancient and historical city of Maimana in Faryab province. $\mathrm{He}$ is one of the prominent graduates of the Faculty of Fine Arts and the most talented artists in painting. The portrait, pencil, and oil works prove his skill and artistry in painting. In his paintings, 
Zhakfar used various tools, and his works done by charcoal, pencil, blue pen, and oil paintings represent his skillful trick.

Zhakfar's high-quality paintings have been exhibited in Afghanistan, Turkey, and Pakistan. The subjects and themes of his paintings are more representatives of the life and environment of Afghan people. His method of working is directly related to Romanism, Realism, and Impressionism (Figures 6-7).

Figure 6: Spring, Oil Painting by Zhakfar,

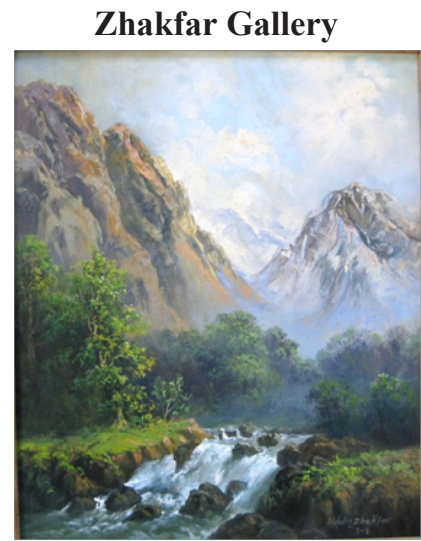

Figure 7: Snow Landscape, Oil Painting by Zhakfar, Zhakfar Gallery

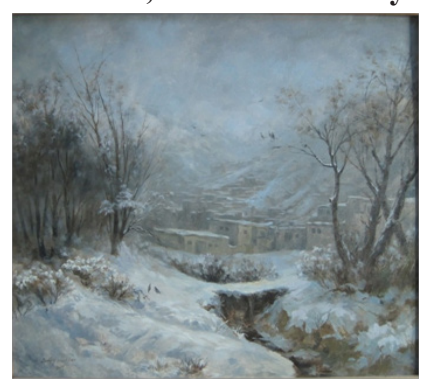

\section{Mohammad Ashraf Anzorgar}

Mohammad Ashraf Anzorgar, son of Mohammadullah Khan was born in 1945 in Kabul. Anzorgar graduated from the Kabul Teacher Training College in 1964 and then started his work as a teacher at Chahar Asia High School. Later, in 1969 was appointed as a teacher at the Gholam Mohammad Mimangi Art Organization. He started working as a professor at the Faculty of Fine Arts in 1977. Anzorgar claims that he is working in the Impressionism style and has created a new technique of Impressionism (Figure 8-9).
Figure 8: Oil Painting by Anzorgar, Anzorgar Gallery

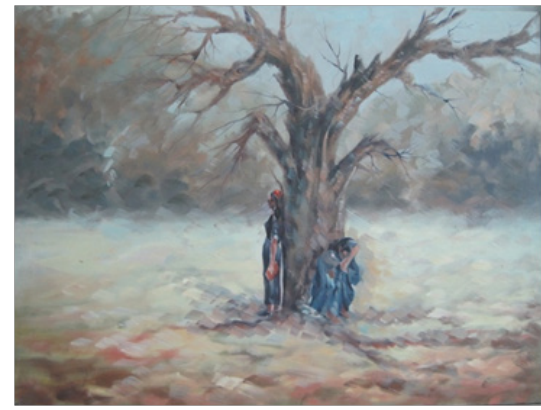

Figure 9: Oil Painting by Anzorgar, Anzorgar Gallery Abdul Wase Rahro Omarzad

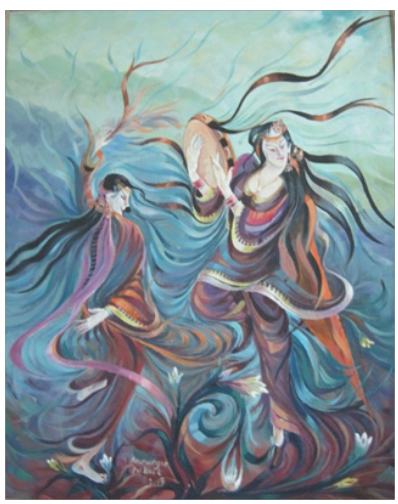

Abdul Wase Rahro Omarzad, son of Dr.Mohammad Omar Salam, was born in Kabul in 1952. He has graduated from the faculty of Fine Arts in Kabul and is currently working as a professor in the painting department of the faculty.

He has done more than a hundred paintings in a realism style. In addition to his teaching duties, Omarzad is also in charge of the Afghanistan Contemporary Art Center. The following are some examples of his works that have been done with watercolors (Figures 10-11).

\section{Figure 10: Old Afghan Man, Watercolor}

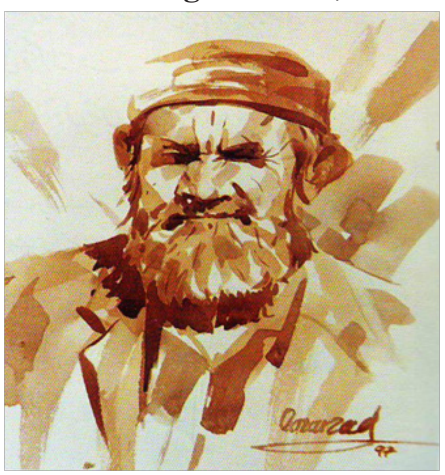

http://www.shanlaxjournals.com 
Figure 11: Barber, Watercolor by Omarzad Latifa Miran

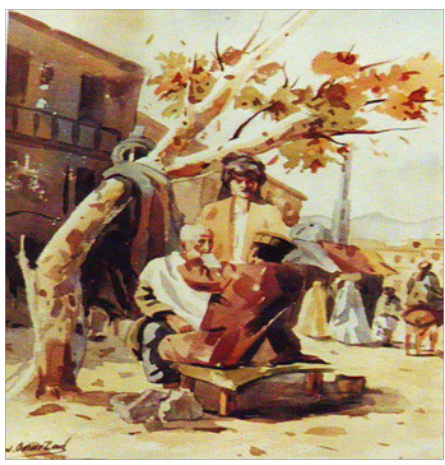

Latifa Miran has Graduated from Amanah Fadavi High School in Kabul in 1987 and entered the Faculty of Fine Arts at Kabul University in 1991.

After completing her higher education in 1994, Miran was included in the cadre of Fine Arts Faculty. She stated that she had previously worked on painting using realism, but her current works are done in a modern style (Figures 12, 13, 14).

Figure 12: Inanimate Nature, Oil Painting by Miran, Miran Gallery

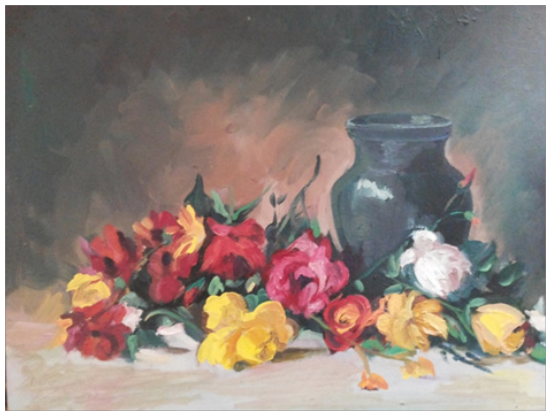

Figure 13: Afghan Girl, Oil Painting by Miran

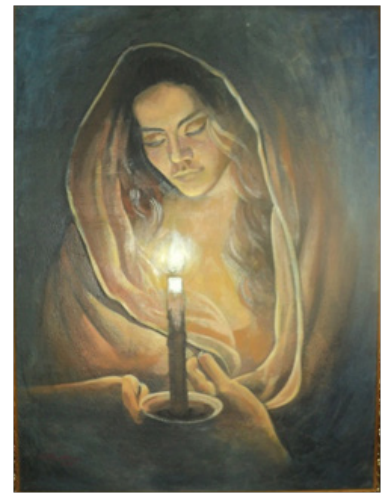

Figure 14 Broken Mirror, Oil Painting by

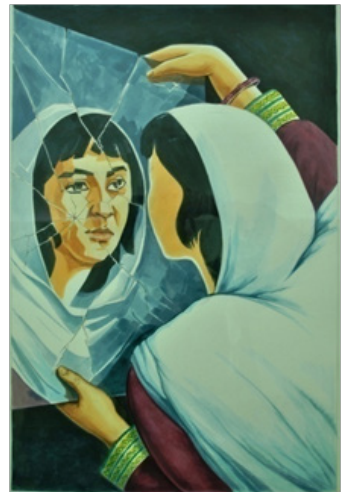

Abdul Wase Hamdard, son of Mohammad Rahim, was born in 1966 in Kandahar province. He has graduated from the Kabul Faculty of Fine Arts. He works in Impressionism and has done many oil paintings, two of which are mentioned below (Figures 15-16).

Figure 15: Buzkashi, Oil Painting by Hamdard Gallery

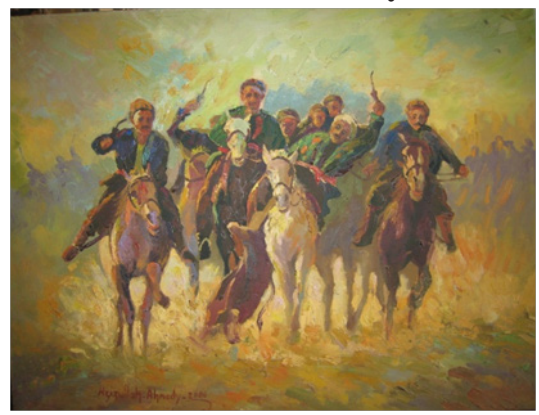

Figure 16 Oil Painting by Hamdard, Gallery

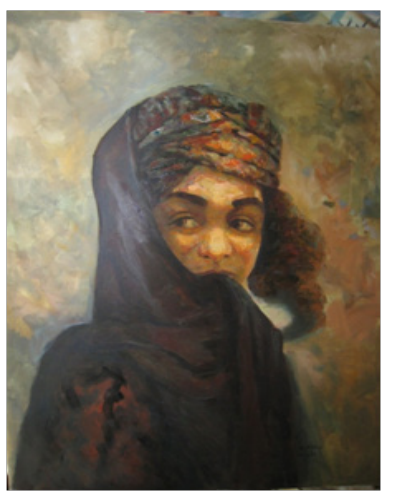

\section{Azizullah Ahmadi}

Azizullah Ahmadi, son of Bismillah, was born in 1966 in Kabul. He has graduated from Kabul University, Faculty of Fine Arts. Ahmadi has created 
many works in classic impressionism styles, two of which can be seen below (Figures 17-18).

Figure 17: Parsa Tomb, Oil painting by Ahmadi

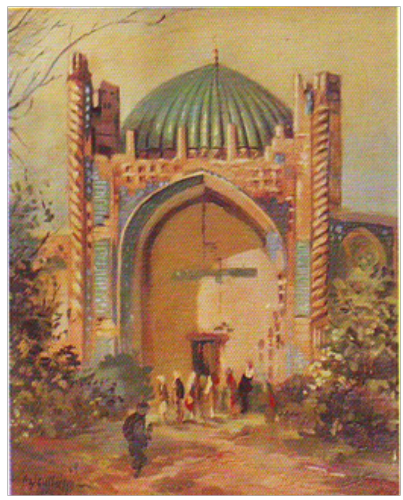

Figure 18: Street, Oil painting by Ahmadi

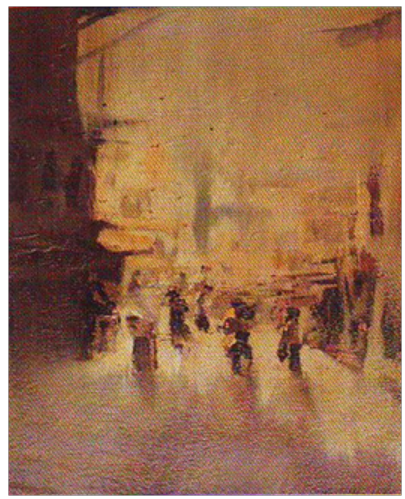

\section{Mohammad Ismail Nikrai}

Mohammad Ismail, son of Habibullah, was born in Kabul in 1967. He completed his higher education in painting in Kerman, Iran. He is currently head of the Nikrai Gallery in Kabul. Niki has been working in painting for about 20 years, and his paintings represent features of impressionism (Figures 19-20).

Figure 19: Street, Oil painting by Nikrai,

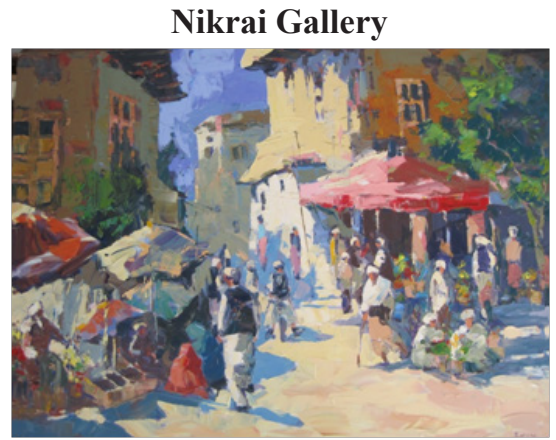

Figure 20: Buzkashi, Oil painting by Nikrai, Nikrai Gallery

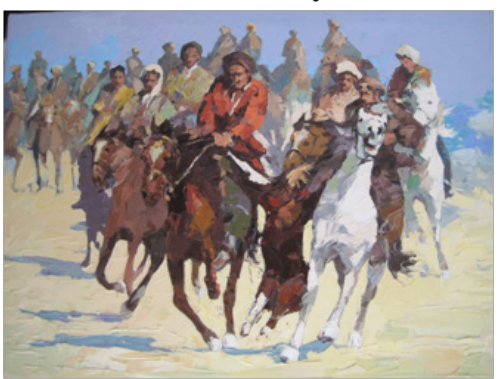

Many examples of the works of famous Kabul painters have been introduced, which according to the author, have been mostly painted in oil paints and realism style except some painters whose new techniques can be seen in their works such as Shabnam, Anzorgar, and Nikrai.

To further explore the art of painting in Kabul, interviews were conducted with professors of Fine Arts faculty of Kabul University, the head of Galleria Gallery, the director of the National Gallery (Nagarstan Melli) in Kabul, the head of the Kabul Institute of Fine Arts and one of Kabul's freelance painters who are introduced as below:

1. Mahtabuddin Zabrdast, Vice-Chancellor of Fine Arts Faculty

2. Enayatullah Niazi, professor of the painting department.

3. Mohammad Ashraf Anzorgar, professor of the painting department.

4. Abdul Wase Rahro Omarzad, head Contemporary Arts Center.

5. Latifa Miran, professor of the painting department.

6. Mohammad Seddiq Zhakfar, professor of the painting department.

7. Abdul Wase Hamdard, a university professor, and painter.

8. Abdul Latif Ghafoori, head of the painting department in the Fine Arts institute of Kabul.

9. Sabera Rahmani, head of the National Gallery in Kabul.

10. Ramin Javid, head of Galleria gallery in Kabul. It worth mentioning that to analyze the issue, the author has discussed in the interviews with arguments and citations of sources. 
What Style and Method do Painters in Kabul use the Most?

There is currently no specific style or method in Kabul. From the beginning of the establishment of Kabul School of Industry, only the technique and skill of simulation have been discussed, which to some extent, the same program continues. (Zabardast).

The tendency of some artists to style is not conscious. Realism must be used in response to the current situation, while artists are conservative in the representation of realism (Omarzad).

There is no specific style or method in Kabul. The artists who claim they are working in a certain style use a mixture of several styles (Latifa Miran).

I have been working in painting for twenty years. At first, I was interested in a realistic style, and soon, I became interested in the Impressionist style because my feelings are consistent with the Impressionist approach (Hamdard).

All people of domestic and foreign, understand, and love realism style more than surrealism, cubism, and abstraction (Ramin Jawid).

The author agrees with the above-mentioned opinions that most painters do not have a unique style and work more in realism. He also adds that realism means that everything happens in an environment, whether good or bad, must be revealed. It doesn't mean we have to paint what we like. Society must be portrayed with its ordinary and important scenes and events. As can be seen in the works of art, the painters of our country pay more attention to the ordinary and pleasant scenes and avoid the abnormal events and realities of society.

Mohsen Keramati, in his book "Introduction to Art Styles and Schools," stated that the artist of realism depicts what he/she sees with a precise vision away from any tendency and belonging. Social realism, which includes social and political issues, is the most important part of nineteenth-century realism. German painters criticized the unfavorable conditions of the time established in an explicit form.

What Subject do you Portray the Most, and Why?

The topics are arising from an artistic feeling (Anzorgar).

People are more interested in Afghanistan, such as Buzkashi, Attan Melli, historical monuments, and
Afghan's daily life, and I use such topics more in my artworks (Jawid).

The school of realism demands realistic subjects. Nowadays, most painters have to do what they are ordered because of their economic problems. The ordered subjects are mostly Afghanistan's sociocultural issues. My favorite subjects that I do most are historical, cultural, and especially Afghanistan, natural landscapes (Zhakfar).

I tried hard to portray the grief and pain of women, and most of my paintings cover the subjects of Afghan women (Miran).

My favorite subjects cover nature, traditional and ancient, inanimate nature, and sometimes historical and political subjects (Hamdard).

The most exhibited works in the Negarestan Gallery have realistic subjects (Rahmani).

Most painters depict Afghanistan's cultural and social issues and its natural landscapes (Ghafoori).

As regards the artistic feeling, I agree with Anzorgar. What matters in art is the feeling, both the feeling of the artist and the emotional impact of the work of art on the audience. According to Tolstoy: Art is a human activity in which the human beings consciously, along with some external symptoms, transmit the emotions that they have experienced to others in such a way that others are affected by these feelings and emotions. When a work of art is created with the artist's inner feeling, it will be impossible to repeat such a work for the second time.

It can be deduced from some of the abovementioned opinions that one of the factors in the uniformity and repetition of subjects in the painting of Kabul is the issue of market demand. Today, foreigners are interested in paintings depicting Afghan themes, which has led painters to focus more on subjects as the historical monuments and the daily lives of the people. On the one hand, it is true that painters are forced to work for the market due to economic problems, or by presenting such topics, they introduce Afghan society to the other nations. But on the other hand, the repetition of works of art will be to the detriment of Afghan painting and the creative power of the artists, which are listed below.

Accepting ordered work and repeating the same way eventually makes the painter always work according to the client's thinking and without 
creativity. A work created with someone else's thinking is not involved in the artist's feelings and thoughts, and such work will not be artistic.

Doing the ordered works constantly with uniformity, on the one hand, slows down the artist's technique and skill in creating a pure work of art. On the other hand, it causes the daily routine of art to gradually moves from state of the art to professionalism (Author).

Leo Tolstoy, in his book "What is Art," states that "significant reward the artists receive in return for their work will be the result of their professionalism".

What is the value and importance of the art of painting in today's Kabul society?

I believe the lack of a gallery for exhibiting works of arts in Kabul is why society's disregard for art, especially painting (Anzorgar).

Omarzad believes that the government's lack of a certain strategy for art, lack of writers and critics to critique literary works in exhibitions, and unprofessional painters are of the reasons for the lack of knowledge about the art of painting in today's society (Omarzad).

Miran proposes that religious and traditional restrictions affect on society for not realizing the true value of the art of painting, and considers it as a form of resistance to art and artists (Latifa Miran).

Because art-loving and art studies are not common in Kabul, today's society does not show their interest in art (Jawid).

In the above comments, issues such as lack of galleries, Islamic restrictions, and lack of attention and planning of the government were mentioned, which are of the factors leading to people disregard the art of painting in Kabul. All the comments are true to a certain extent, but I believe that our artists are also responsible for introducing and developing the art of painting by organizing painting exhibitions (Author).

\section{How do you Measure the Interest of Students (Faculty of Fine Arts) in Modern Painting?}

The main motivation for establishing the Afghanistan Contemporary Art Center in Kabul was to save our visual and drawing arts from monotony and limitations (Omarzad).

At the Faculty of Fine Arts in Kabul, a limited number of students are interested in modern painting. But this interest was more subconscious, and they wanted to experience this art as a new subject. In my opinion, what do we know from classical art so far to turn to modern painting? Painting is still very new to our society. The art of the past and the schools of art that have evolved in Europe have not yet evolved so much here to put them aside like other countries. Additionally, modern painting is a new phenomenon related to democracy and has entered to society simultaneously with democracy, so there is no ground for its study (Zabardast).

Most painting lovers in Afghanistan are interested in painting realistic subjects because they can better understand the subjects through realism painting (Zhakfar).

Modern painting has been introduced to youths and students so that, if they tend to use the style, they will go to the evil way and may deviate from the style of realism (Anzorgar).

Students are very interested in modern painting because they are tired of painting realism. Nowadays, the expression is valuable, so students are so interested in modern art (Miran).

Hamdard likened modern painting to cloth, saying that dressing cloth has a culture that we do not have (Hamdard).

In the above discussion, there is no consensus among university professors. Omarzad and Miran are almost in agreement on modern painting. Zabardast, Anzorgar, and Hamdard have expressed dissenting opinions. The author agrees with Omarzad and Miran and adds with documentary and citation:

Realism, indeed, is an art that artists have been dealing with for years, and people realize that reality better. But it doesn't mean we don't pay attention to modern painting. The purpose is no to do certain modern or abstract painting; rather, it is about innovation and initiatives, which is achieved by studying the theory and practice of various works and the artist's creativity. Many years have passed since the establishment of Kabul School of Industry, but most of our painters still work in a realism style. If we proceed in the same way, modern painting may always be new to us. So we need to encourage young people to study art schools and movements alongside realism to create new masterpieces and let 
them free in doing creative works. According to Leo Tolstoy in his book of "What is Art?", the product of thought is considerable when it transmits new ideas and thoughts to others and does not repeat known subjects, similarly brings a new feeling into the normal course of human life.

\section{What has Changed in the Field of Painting in Kabul in Recent Years?}

I feel a kind of silence in the art of painting at Kabul (Niazi).

There has been done lots of activity in the art of music, but unfortunately, no attention has been paid to the development of the art of painting (Anzorgar).

Wars and, to some extent, religious prejudices and people's ignorance of culture and artistic knowledge have prevented painting from finding its position in society (Zhakfar).

The developments in painting have taken place since 2002 in Kabul, and Afghan painters' visons have widened (Miran).

Artists are still adherent to realism and romanticism subjects, and the art of painting has not changed much in recent years (Hamdard).

Much works have been done on the art of painting, and the young students have taken some initiatives in this field (Jawid).

There are two art forms currently ongoing in Kabul. One is conservative. The other is the liability, which is being formed recently and have not yet found their true objectivity and have not affected the general situation of the art of painting (Omarzad).

The state of painting in central Afghanistan (Kabul) is disappointing and rooted in Kabul's misery and war (Zabardast).

In the above comments, the majority believe that painting in the current situation of Kabul, in terms of insecurity, war, religious prejudice, lack of public awareness, has failed to grow and evolve. However, the minority believes that in recent years, there has been a shift in the field of painting, considering artists traveling abroad. Whenever there is a discussion of art and artist, both in Kabul and in other provinces, issues such as the conditions of war and religious prejudices arise. In terms of war and insecurity in the current situation in Kabul, I agree with their opinion. But in other countries, such as Russia and Germany, their artists, given the same conditions, reflected realities, anomalies, and pains of their time and even gained fame with their artworks (Author).

\section{Conclusion}

The conclusion of this research is based on observations, research findings, and discussion. To get a better result, first, each question is answered, and the overall result is explained in the end.

There is no specific style or method of painting in Kabul, and most painters follow the realistic style. This style was taught simultaneously to establish the Kabul School of Industry by Gholam Mohammad Maimanagi and Abdul Ghafoor Breshna and is continuing. This method aims at expressing the realities of society with the good and bad events of life. But the majority of Kabul's existing painters depict the positive aspects and normal lives of the people.

The working subjects of the painters in Kabul often consist of the cultural, historical, and daily life of the people. There is less evidence of political issues and incidents and anomalies. Presumably, one of the factors is the market demand, especially foreigners to such subjects.

Due to the economic problems and the government's negligence, the painters turned to the ordered works. The repetition of the orders has led to the uniformity of painting and the artists' lack of creativity.

The art of painting is not much important in today's Kabul society. People do not have complete knowledge of this art. That is because of a lack of government special strategy, lack of suitable galleries to exhibit artworks, and the lack of art critics.

-Kabul Contemporary Art Center is being improved, has not yet found its clear identity, and has not been very influential on the general situation of Kabul. Young people are less interested in modern painting, but this interest is subconscious, and they want to experience it as a new subject.

In general, we conclude that painting in the current situation of Kabul, in terms of insecurity, war, religious prejudices, irresponsibility of the Ministry of Information and Culture, and lack of public awareness, has relatively lost its evolution and development. Only technically, some changes are 
observed in the works of painters. Since 2002, due to the artists travel outside Afghanistan, there have been relative shifts in painting, and their visions have widened. The painters' attempt to find a unique and new method is observed in some artworks. But the majority of the works are doing in realism style in an old and repetitive method.

\section{References}

Breshna, Habiba, et al. The Kabul Bazaar - The Intersection of Cultures, Vontobe Druck AG, Wetzikon, 2001.

Faryad, F. "A Brief Review of Afghanistan's Visual Arts." Scientific Journal of Kabul University. 2010.

Goodarzi, M. On the Evolution of Herat school, 2004.
Graham, Gordon. Philosophy of the Arts, translated by Massoud Olya, 2004.

Kohzad, Y. "Gholam Mohammad Maimanagi and Breshna are Two Familiar Figures in the History of our Contemporary Painting." Art, vol. 3 , no. 4, 1984, pp. 13-15.

Saljoghi, H. "Painters Styles of Khorasan and Its Artistic Primary Schools." Art, vol. 3, 1983, pp. 16-21.

Shabnam, M. Afghan Immigrant Painters, UNESCO, 2002.

Shahrani, E. Art in Afghanistan, Danesh Press, 1971.

Shahrani, E. Contemporary Afghan Portraitists, 2013.

Tolstoy, Leo. What is art?, translated by Kaveh Dehgan, 2009.

Vakili, A. "An Attitude towards the Artistic Life of Breshna." Art, vol. 4, no. 2, 1985, pp. 15-18.

\section{Author Details}

Abdul Qadir Sarwari, Assistant Professor, Herat University, Afghanistan, Email ID: a_qadir_sarwary@yahoo.com 